\title{
Coccinellidae beetles (Coleoptera) fauna of district Layyah (Punjab), Pakistan
}

\author{
Muhammad Adnan Bodlah¹, Imran Bodlah2², Muhammad Tariq Rasheed², Ammara Gull e Fareen ${ }^{2,4}$, \\ Kamran Ikram ${ }^{1}$, Zafar Iqbal'2, Roshan Zada ${ }^{3}$ \\ ${ }^{1}$ Fareed Biodiversity Conservation Centre, Department of Agricultural Engineering, Khwaja Fareed University of \\ Engineering and Information Technology, Rahim Yar Khan, Punjab, Pakistan \\ ${ }^{2}$ Insect Biodiversity and Conservation Group, Department of Entomology, Pir Mehr Ali Shah Arid Agriculture University, \\ Rawalpindi, Pakistan \\ ${ }^{3}$ Director Technical, Pakistan Agricultural Research Council, Islamabad, Pakistan \\ ${ }^{4}$ Department of Environmental Sciences, Pir Mehr Ali Shah Arid Agriculture University, Rawalpindi, Pakistan
}

Received:

June 7, 2020

Accepted:

October 11, 2020

Online First:

December 09, 2020

Published:

January 30, 2021

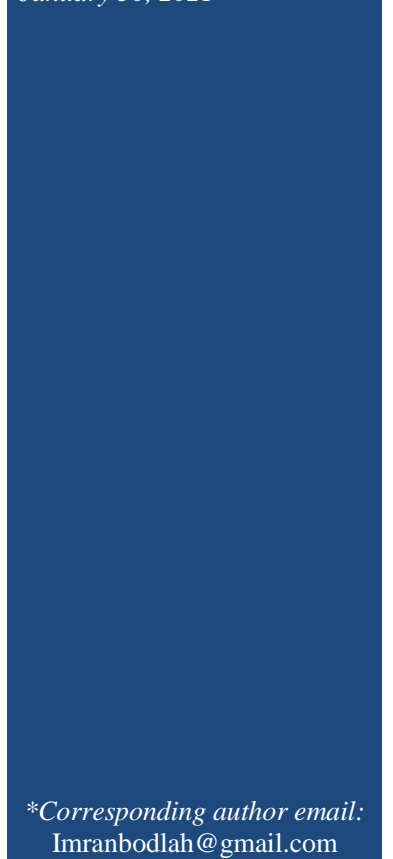

\section{Abstract}

Beetles belonging to family Coccinellidae are predators of various sucking insect pests, some of them are phytophageous. A lot of work for the exploration of these beetles has been done in Pakistan. Layyah being a multi crop area was selected as study area for the exploration of Coccinellidae beetles. A survey was conducted for the collection of Coccinellidae adult specimens from the territory of Layyah district of southern Punjab, Pakistan, during 2018-19. A total 568 adult specimens were collected from seven localities. Out of which, ladybird beetles belonging to seven genera, with ten species namely; Coccinella septempunctata Linnaeus, 1758, Brumoides suturalis (Fabricius, 1798), Henosepilachna vigintioctopunctata (Fabricius, 1775, Henosepilachna elaterii (Rossi, 1794), Hippodamia variegata (Goeze, 1777), Scymnus (Pullus) quadrillum Motschulsky, 1858, Scymnus (Pullus) posticalis Sicard, 1913, Scymnus (Scymnus) nubilus Mulsant, 1850, Micraspis allardi (Mulsant, 1866), Pharoscymnus flexibilis (Mulsant, 1853), have been recorded with their prey and host plants for the first time from the surveyed area. The coccinellids distribution is also given and map was prepared by using ArcGIS map tool. Explored predatory beetles may be used as biocontrol agents in the region for the management of various sucking insect pests of various crops, fruits vegetables etc.

Keywords: Ladybird beetles, Coccinellidae, Predators, Diversity, Taxonomy, Layyah, Punjab

\section{How to cite this:}

Bodlah MA, Bodlah I, Rasheed MT, Fareen AGE, Ikram K, Iqbal Z and Zada R, 2021. Coccinellidae beetles (Coleoptera) fauna of district Layyah (Punjab), Pakistan. Asian J. Agric. Biol. 2021(1). DOI: https://doi.org/10.35495/ajab.2020.05.299

This is an Open Access article distributed under the terms of the Creative Commons Attribution 3.0 License. (https://creativecommons.org/licenses/by/3.0), which permits unrestricted use, distribution, and reproduction in any medium, provided the original work is properly cited.

\section{Introduction}

The voracious and non-specialist predator, beetles belong to the family Coccinellidae, are the beneficial insects for having ample impacts on diverse insect pest species like aphids, mites, scale insects, whiteflies (Obrycki and Kring, 1998). The predatory behavior of the Coccinellidae varies within the species as they 


\section{Muhammad Adnan Bodlah et al.}

have a positive impact by feeding on the insect pests and intraguild cannibalism included in their negative feeding behavior (Lucas, 2012). Most of the species are economically important predators, while some are also plant or being mycetophagous (Sutherland and Parrella, 2009). So, the predatory behavior of the Coccinellids includes different transitions throughout different trophic levels which covers primary carnivores to herbivorous insect. Similarly, the female Coccinellids are being proved stronger predators than the male beetles (Chowdhury et al., 2008).

Most of the Coccinellidae species adults are with bright and shining color patterns with patches or spots against the contrasting backgrounds. Similarly, these color patterns have been found defensive as signs of warning or danger or distasteful for their bird predators (Moreton, 1969). The farmers usually spray pesticides to kill pests extensively which kills both the pests and their natural enemies. The indiscriminate use of chemicals may affect lady bird beetles searching behavior, feeding behavior, mating behavior, number of eggs, and overall life span (Alinejad et al., 2014; Afza et al., 2020). However, ladybird beetles have great potential to survive the lethal effects of applied chemicals which makes them preferable for any integrated pest management (Mughal et al., 2017)

According to the latest classifications, Coccinellinae Latreille, 1807 and Microweiseinae Leng, 1920, are now subfamilies of Coccinellidae family (Slipinski, 2007; Seago et al., 2011). Moreover, it is reclassified to superfamily Coccinelloidea (Coleoptera: Polyphaga: Cucujiformia) (Robertson et al., 2015). Overall, more than 6000 species with 360 genera have been reported worldwide. Additionally, more than 300 species have been reported from Indo-Pak subcontinent and more than 71 species specifically from Pakistan. (Fleming, 2000; Irshad, 2001; Boopathi et al., 2020). Most recently and locally, Irshad (2001) 71 species, Rafi et al. (2005) 75 species, Khan et al. (2007) 12 species, Ali et al. (2014a, 2014b, 2015) 29 species, Ahmed et al. (2017) 9 species, Iqbal et al., (2017, 2018, 2019a, 2019b, 2020) 5 species, described predatory ladybird beetles with their associated prey insect pests from different locations of provinces in Pakistan. However, till now there is still deficiency of information about this economically important biological control agent's family from Pakistan. The current study was intended to explore the ambiguous species riches and distribution of Coccinellidae family from the district Layyah of Punjab, Pakistan.

\section{Material and Methods}

\section{Area surveyed for collection}

Multiple surveys were carried out in the district Layyah during 2018-19 to collect ladybird beetles, which covers an area of $6,291 \mathrm{~km}^{2}$ with its geographical presence as $30^{\circ} 58^{\prime} 15.2^{\prime \prime} \mathrm{N}$ and $70^{\circ} 566^{\prime} 39.6$ "E. The major cereal crops are (wheat, millet, barley, rice), oil seed crops (sunflower, linseed and rapeseed), pulses (gram, mash, masoor, moong), fodder (maize, millet, Alfalfa, barley), fruits (citrus, date palm, guava, jamun, mango) and vegetables (potato, radish, carrot, cauliflower, onion, garlic, green pepper) are grown in district Layyah.

\section{Collection and identification}

The ladybird beetle specimens were collected in the morning (8:00-10:00 am) and afternoon (2:00 to 4:00 pm) from different intended areas of district Layyah as shown in figure 1. The ladybird beetle's distribution map is prepared by using ArcGIS map tool. The adult ladybird beetles were collected through hand-picking and net sweep method and killed by using cyanide insect killing glass bottle (Iqbal et al., 2017). The killed specimens were brought to the insect taxonomy laboratory of Fareed Biodiversity Conservation Centre, Department of Agricultural Engineering, Khwaja Fareed University of Engineering and Information Technology, Rahim Yar Khan, Punjab, Pakistan, and preserved in wooden boxes.

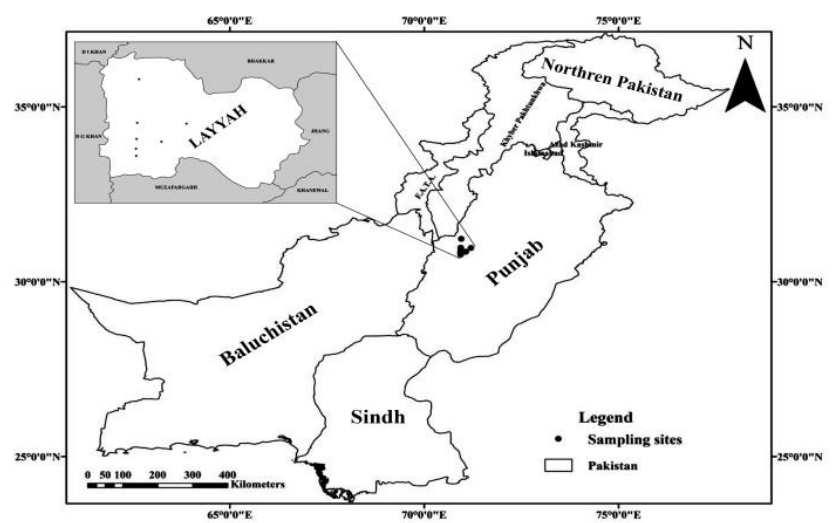

Figure-1. Distribution map of collected coccinellid specimens from Layyah district of Punjab, Pakistan.

Each specimen was pinned and mounted on small triangular plastic card tips with the labelling information of their locality, date of collection, host plants etc. Before placing specimens, the wooden 
boxes were treated with Coopex Powder (®) and naphthalene tablets were placed to deter the other insects feeding on preserved insects. The morphological and taxonomic characters of ladybird beetles were studied on the basis of available published literature and checklists by Poorani, (2002), Rafi et al. (2005), Ali et al. (2015, 2018), Ashfaque et al. (2015) and other website links like NBAII, (2009) under the microscope ZMS 2000 compound microscope. However, Photographs of the adult specimens were taken using Nikon Digital camera (SMZ 1500), which was attached to the stereo microscope and photographs were processed by using Helicon focus 6.7.1 and Adobe Photoshop CS 6.0.

\section{Results}

\section{Coccinella septempunctata Linnaeus, 1758 (Fig. 2a)}

\section{Material examined}

Karor Lal Esan, $7 q$ and $6 \AA$, Chowk Azam, $12 q$ and 14 ${ }^{\lambda}$; Jaman Shah, $9+$ and 5 ${ }^{\lambda}$; Kot Sultan, 14 and 3 ${ }^{\lambda}$; Ladhana, $7 q$ and $13 \hat{\partial}$, Layyah, $6 \rho$ and $2 \hat{\sigma}$

\section{World distribution}

Indo-Pak, Indo-China subcontinents, New Zealand, Indonesia, Australia, Japan, Nepal, (Poorani 2002).

\section{Prey species with host plants}

Aphis gossypii (Glover), Brevicoryne brassicae (L), Schizaphis graminum (Rondani), Myzus persicae (Sulzer), Phenacoccus solenopsis (Tinsley) and Amrasca biguttula biguttula (Ishida) on cotton, mustard, cabbage, potato, okra, wheat and rose plants respectively.

\section{General comments}

Coccinella septempunctata found similar with the given diagnostic characters description by Ali et al. (2018) and first time reported from Layyah district.

\section{Brumoides suturalis (Fabricius, 1798) (Fig. 2b)}

\section{Material examined}

Karor Lal Esan, $4 q$ and $\lesssim 2$, Chowk Azam, $11 q$ and

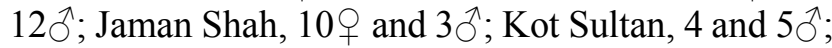
Ladhana, $2 q$ and $7 \hat{\partial}$, Hafiz Abad, 29 and $2 \hat{\jmath}$

\section{World distribution}

Bhutan, Pakistan, Sri Lanka, Nepal, India, Bangladesh (Poorani, 2002)
Prey species with host plants

Lipaphis erysimi (Kaltenbach), Myzus persicae (Sulzer), Macrosiphum granarium (Kby), Brevicoryne brassicae (L.), Aphis craccivora Koch, Ropalosiphum maidis (Fitch), Phenacoccus solenopsis (Tinsley), Amrasca devastans (Dist), Drosicha mangiferae (Green), Amrasca biguttula biguttula (Ishida) on plant host like potato, lucern, eggplant, okra, flowers and weeds.

\section{General comments}

Brumoides suturalis found similar with given diagnostic characters description by Ali et al. (2018) and first time reported from Layyah district.

\section{Henosepilachna vigintioctopunctata (Fabricius, 1775) (Fig. 2c)}

\section{Material examined}

Karor Lal Esan, $2 q$ and $\lesssim 3$, Chowk Azam, $5+$ and 14 $\overbrace{}^{\lambda}$; Layyah, $3 \propto$ and $5{ }^{\lambda}$ Jaman Shah, $8+$ and $3{ }^{\lambda}$; Kot Sultan, 8 and $2 \hat{\jmath}$.

\section{World distribution}

Reported from different European, African and Asian countries of the world. (Katoh et al., 2014)

\section{Host plants}

Being a phytophagous pest from coccinellid family, was found on Solanaceous and Cucurbitaceae family vegetables including tomato, potato, bitter gourds and pumpkins.

\section{General comments}

This species also named as Hadda beetle. Henosepilachna vigintioctopunctata found similar with given diagnostic characters description by Ahmed et al. (2017). This species first time reported from district Layyah.

Henosepilachna elaterii (Rossi, 1794)

(Fig. 2d)

\section{Material examined}

Karor Lal Esan, $5 q$ and 69 , Layyah, $7 q$ and $2 \hat{\sigma}$ Jaman Shah, $9 \odot$ and 6 ${ }^{\lambda}$; Kot Sultan, 4 and $5{ }^{\lambda}$

\section{World distribution}

Middle East, Madagascar, Africa, South Europe and Asian countries. (Katoh et al., 2014).

\section{Host plants}


It's a phytophagous invasive pest of Cucurbitaceae family vegetables like pumpkins.

\section{General comments}

Henosepilachna elaterii also known as Melon ladybird beetle first time reported from Layyah district and found similar with given diagnostic characters description by Ahmed et al. (2017).

\section{Hippodamia variegata (Goeze, 1777)}

(Fig. 2e).

\section{Material examined}

Karor Lal Esan, 49 and 2, Chowk Azam, 119 and 12 ${ }^{\lambda}$; Jaman Shah, $10 \bigcirc$ and 3 ${ }^{\lambda}$; Kot Sultan, $4 ㅇ$ and $5 \hat{\gamma}$; Ladhana, $2 q$ and $7 \hat{\partial}$, Hafiz Abad, $2 q$ and $2 \hat{\sigma}$

\section{World distribution}

Afghanistan, India, China, Pakistan, Africa, Nepal (Poorani, 2002).

\section{Prey species with host plants}

Aphis punicae Passerini, Lipaphis erysimi (Kaltenbach), Aphis gossypii (Glover), Schizaphis graminum (Rondani), Brevicoryne brassicae (L.), Hyadaphis coriandri (Das), Myzus persicae (Sulzer), Amrasca biguttula biguttula (Ishida) and Bemisia tabaci (Gennadius) on different plant hosts like lucern, potato, turnip, brinjal, okra, cotton, wheat mustar and weeds.

\section{General comments}

Hippodamia variegata found similar with given diagnostic characters description by Ali et al. (2018) and first time reported from Layyah district.

Scymnus (Pullus) quadrillum Motschulsky, 1858 (Fig. 2f)

\section{Material examined}

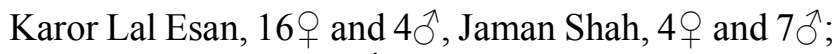
Kot Sultan, $11+$ and $9{ }^{\Uparrow}$

\section{World distribution}

Pakistan, Vietnam, Nepal, Laos, Bangladesh, India, Taiwan, China, Thailand (Ali et al., 2015).

\section{Prey species with host plants}

Brevicoryne brassicae (L.), Aphis gossypii (Glover), and Aphis punicae Passerini on different crops and fruit plants.

\section{General comments}

Scymnus (Pullus) quadrillum found similar with given diagnostic characters description by Ali et al. (2015) and first time reported from Layyah district Scymnus (Pullus) posticalis Sicard, 1913 (Fig. 2g).

\section{Material examined}

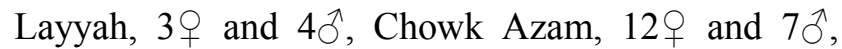
Jaman Shah, $7 \uparrow$ and 5 ${ }^{\lambda}$; Kot Sultan, $13 q$ and 14 $\overbrace{}^{\lambda}$

\section{World distribution}

African, European and very common in Asian countries like India, Nepal, Pakistan. (Ashfaque et al., 2015).

\section{Prey species with host plants}

Generally, it feeds on aphid species like Aphis punicae Passerini, Myzus persicae (Sulzer), Aphis craccivora Koch, Brevicoryne brassicae (L.), Aphis gossypii (Glover), phytophagous mites and scale insects on different weeds and fruit plants like grapes, apples.

\section{General comments}

Scymnus (Pullus) posticalis found similar with given Diagnostic characters description by Ashfaque et al. (2015) and first time reported from Layyah district.

Scymnus (Scymnus) nubilus Mulsant, 1850 (Fig. 2h).

\section{Material examined}

Karor Lal Esan, $13 q$ and $6 \hat{0}$, Layyah, $2 q$ and $3 \hat{\jmath}$, Chowk Azam, $5 q$ and $\lesssim 2$, Jaman Shah, $6 \propto$ and 3 $3{ }^{\lambda}$; Kot Sultan, +2 and $4{ }^{\Uparrow}$

\section{World distribution}

Pakistan, Myanmar, Nepal, Bangladesh, China, Sri Lanka, Indian (Ashfaque et al., 2015)

\section{Prey species with host plants}

This species feed on different life stages of insect pests like, Myzus persicae (Sulzer), Aphis craccivora Koch, Brevicoryne brassicae (L.), Aphis gossypii (Glover), Lipaphis erysimi (Kaltenbach), Drosicha mangiferae (Green) and Bemisia tabaci (Gennadius) on different corps, fruit, flowering and weed plants.

\section{General comments}

Scymnus (Scymnus) nubilus found similar with given diagnostic characters description by Ashfaque et al. (2015) and first time reported from Layyah district. 


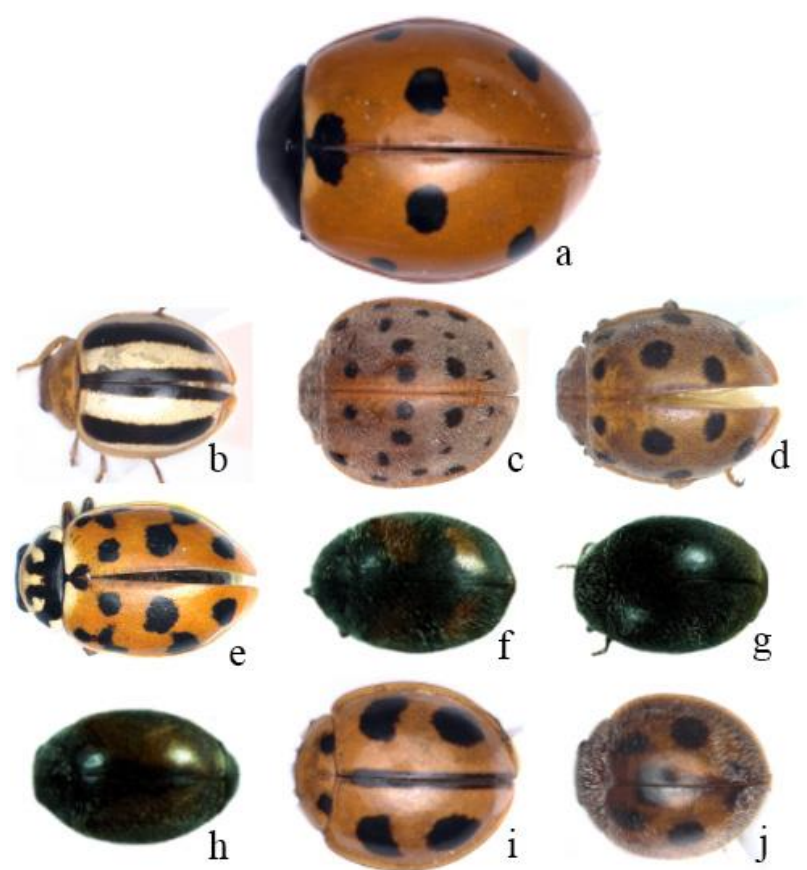

Figure-2 (a-j): (a) Coccinella septempunctata Linnaeus, 1758; (b) Brumoides suturalis (Fabricius, 1798); (c) Henosepilachna vigintioctopunctata (Fabricius, 1775); (d) Henosepilachna elaterii (Rossi, 1794); (e) Hippodamia variegata (Goeze, 1777); (f) Scymnus (Pullus) quadrillum Motschulsky, 1858; (g) Scymnus (Pullus) posticalis Sicard, 1913; (h) Scymnus (Scymnus) nubilus Mulsant, 1850; (i) Micraspis allardi (Mulsant, 1866); (j) Pharoscymnus flexibilis (Mulsant, 1853).

Micraspis allardi (Mulsant, 1866)

(Fig. 2i).

\section{Material examined}

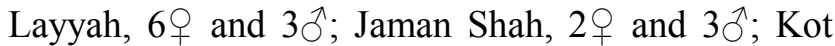
Sultan, 4 and 2 ${ }^{\lambda}$; Ladhana, $2 \propto$ and $3 \hat{\circ}$,

\section{World distribution}

Indonesia, Pakistan, Nepal, Myanmar, Nepal, Bangladesh (Poorani 2002; Ali et al., 2018)

\section{Prey species with host plants}

Quadraspidiotus perniciosus Comst, Amritodus atkinsoni Teth, Pyrilla perpusilla Walk and Macrosiphum granarium (Kby), on different crops, fruits and weed host plants.

\section{General comments}

Micraspis allardi found similar with given diagnostic characters description by Ali et al. (2018) and first time reported from Layyah district.

Pharoscymnus flexibilis (Mulsant, 1853) (Fig. 2j).

\section{Material examined}

Layyah, $11 q$ and $6 \hat{\jmath}$; Jaman Shah, 49 and 2^; Kot Sultan, 5 and $7 \hat{\partial}$; Ladhana, $7 q$ and $7 \hat{\partial}$, Hafiz Abad,

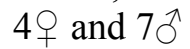

\section{World distribution}

USA, Pakistan, Brazil, India, (Poorani 2002; Ali et al., 2018)

\section{Prey species with host plants}

Schizaphis graminum (Rondani), Aphis craccivora Koch, Siassetia nigra (Nietn) and Aspidiotus destructor Sign, on host plants like lucern, wheat, mustard, cotton, grams.

\section{General comments}

Pharoscymnus flexibilis found similar with given diagnostic characters description by Ali et al. (2018) and first time reported from Layyah district.

\section{Discussion}

The current surveys were anticipated to explore the indigenous Coccinellidae fauna from southern Punjab district Layyah. A total of 10 species belonging to 7 genera with their prey, associated host plants and distribution were recorded. Previously Poorani (2002) from India, Ali et al. $(2015,2018)$ from Sindh province, Ashfaque et al. (2015) from Northern area of Pakistan, Ahmed et al. (2017) from Sargodha, Gilani (1976) from Faisalabad and Rafi et al. (2005) from different localities of Pakistan reported these species. Other than these species, Shah (1985) reported about sixteen ladybird species with their distribution and pests host plants from Peshawar. Hussain et al. (2018) described four species from rainfed and irrigated localities of Gujrat. Din (2002) reported similar species from Chitral and Rafi et al. (2005) surveyed Districts of Azad Kashmir areas and reported similar seventy-five predatory ladybird beetles. Whereas, according to Abbas et al. (2013), there are about 91 species have been reported from Pakistan.

Irshad (2001) studied the biotic potential, ecology, distribution and host of Coccinellids from Pakistan. Moreover, Coccinellidae distribution and diversity from District Dir Lower Pakistan have been studied by Rahatullah et al., 2011. Coccinellidae regional distribution record of Gilgit-Baltistan was given by Ashfaque et al. (2013). Similarly, different predacious Coccinellids have been reported from different 


\section{Muhammad Adnan Bodlah et al.}

districts of Khyber Pakhtunkhwa province of Pakistan like Nowshera, Mardan and Sawabi with species richness, diversity and dominance by Urooj and Ali, 2016.

The persuasion for higher crops production has been directed towards intensive farming systems. That, however, become the reason for high pest populations followed by high intensity pesticides usage and other pest control techniques. The current study will be supportive in mass production of ladybird beetles against pests, reduction in number of insecticide applications and ultimately helping in reduction of environmental pollution.

\section{Conclusion}

The current study results contribute to a baseline to study ladybird beetle's ecology, biology, phytophagy, and predatory behavior against different pests. The current reported species of Coccinellidae family were diversified and abundant. These species may be utilized as potential biological control agents after evaluating their predatory potentials. Finally, it leads the researchers towards the conservatory biological control strategies for the endemic plant protection programs.

\section{Acknowledgement}

The authors of this manuscript would like to thank Dr. Zafer Iqbal for providing literature and supporting in specimen's confirmation.

Disclaimer: None.

Conflict of Interest: None.

Source of Funding: None.

\section{References}

Abbas MN, Kausar S and Rana SA, 2013. Diversity and distribution of ladybird beetles (Coccinellidae) in the cropland of Faisalabad district. International J. Adv. Res.1:27-33.

Afza R, Riaz MA and Afzal M, 2020. Sublethal Effect of Six Insecticides on Predatory Activity and Survival of Coccinella Septempunctata (Coleoptera: Coccinellidae) Following Contact with Contaminated Prey and Residues. Gesunde Pflanzen. 72:77-86.

Ahmed KS, Majeed MZ, Rafi MA, Sellami F and
Afzal M, 2017. Biodiversity and Species Distribution of Coccinellids (Coccinellidae: Coleoptera) in District Sargodha (Punjab), Pakistan. Pak. J. Zool. 49: 5

Ali M, Perveen R, Yusouf MJ, Khawaja S and Amin M, 2014a. Predatory potential of five coccinellids against cotton mealy bug Phenacoccus solenopsis (Tinsley) from Sindh, Pakistan. Pak. Entomol. 36: 7-12.

Ali M, Naqvi AN, Perveen R, Ahmad K and Hussain I, 2014b. First Record of the Tribe Bulaeini

(Coleoptera: Coccinellidae) With Generic and Species Descriptions from Pakistan. Pak. J. Zool. 46: 1475-1478.

Ali M, Perveen R, Naqvi AN, Ahmed K, Raza G and Hussain I, 2015. The Tribe Scymnini (Coccinellidae: Coleoptera) From Sindh Province, Pakistan. J. Insect. Sci. 15: 146.

Ali M, Ahmed K, Ali S, Raza G, Hussain I, Nafees MA and Anjum SI, 2018. An annotated checklist of Coccinellidae with four new records from Pakistan (Coleoptera, Coccinellidae). ZooKeys. 93: 803.

Alinejad M, Kheradmand K and Fathipour Y, 2014. Sublethal effects of fenazaquin on life table parameters of the predatory mite Amblyseius swirskii (Acari: Phytoseiidae). Exp. Appl. Acarol. 64:361-373.

Ashfaque M, Ullah F, Rafi MA and Naz F, 2015.Taxonomic study of subfamily Scymninae (Coleoptera: Coccinellidae) with one new record from Gilgit-Baltistan, Pakistan. Turk. J. Zool. 26:1034-1040.

Ashfaque M, Ullah F and Rafi MA, 2013. Genus Coccinella (Coccinellidae: Coleoptera) from Gilgit-Baltistan with two new records from Pakistan. Sarhad J. Agric. 29: 2

Boopathi T, Singh SB, Dutta SK, Dayal V, Singh AR, Chowdhury S, Ramakrishna Y, Aravintharaj R, Shakuntala I, Lalhruaipuii K. Harmonia and Sedecimnotata F, 2020. Predatory potential, biology, life table, molecular characterization, and field evaluation against Aphis gossypii Glover. Sci. Rep. 10:1-10.

Chowdhury SP, Ahad MA, Amin MR, Amin MR and Rasel NA, 2008. Bean aphid predation efficiency of lady bird beetle Micraspis discolor F. (Coleoptera: Coccinellidae). J. Soil Nat. 2: 40-45.

Din S, 2002. Distribution of Predatory Coccinellid (Coleoptera: Coccinellidae) beetles in District Chitral. Dept of Plant Protect (Doctoral 
dissertation, M. Sc. Thesis. NWFP Agric Univ Peshawar, Pakistan.

Fleming RC, 2000. Lady beetles. Entomological Notes No.6. Published as a service of Michigan Entomological Society. http://insects.ummz.lsa.umich.edu/MES/notes/ent notes6.html

Gilani WA, 1976. Studies on the predaceous Coccinellidae of Lyal Pur. M.Sc. Thesis, University of Agriculture, Faisalabad, Pakistan

Hussain M, Malik MF, Siddique S, Umar M, Zainab T and Zafar F, 2018. Diversity and Distribution of Coccinellid Beetles in Irrigated and Rainfed Fields of Gujrat, Punjab, Pakistan. Punjab Univ. J. Zool. $33: 1-6$.

Iqbal Z, Nasir MR, Bodlah I, Qureshi R and Aihetasham A, 2017. Notes on three morphs of Bulaea lichatschovii (Hummel) (Coleoptera: Coccinellidae) from Northern Pakistan. Punjab Univ. J. Zool. 32: 203-208.

Iqbal Z, Nasir MF, Bodlah I and Qureshi RA, 2018. Contribution to the genus Rodolia Mulsant, 1850 (Coleoptera: Coccinellidae) from Pothwar Plateau of Pakistan. J. Anim. Plant Sci. 28: 4.

Iqbal Z, Nasir MF, Bodlah I, Szawaryn K, Khormizi MZ and Hassan MA, 2019a. A review of the genus Hyperaspis Chevrolat, 1837 (Coleoptera: Coccinellidae) from Pakistan. Orient. Insects. 2: 58-76.

Iqbal Z, Nasir MF and Bodlah I, 2019b. Szawaryn K. Review of Clitostethus Weise, Parastethorus Pang et Mao and Stethorus Weise (Coleoptera: Coccinellidae) from Pakistan. Orient. Insects. 3: 340-355.

Iqbal Z, Nasir MF and Bodlah I, 2020. A new species of Sasajiscymnus Vandenberg (Coleoptera: Coccinellidae) from Pakistan. Zootaxa. 3: 379390.

Irshad M, 2001. Distribution, host, ecology and biotic potential of Coccinellids of Pakistan. Pakistan J. Bio. Sci. 4: 1259-1263.

Katoh T, Koji S, Ishida TA, Matsubayashi KW, Kahono S, Kobayashi N, Furukawa K, Viet BT, Vasconcellos-Neto J, Lange CN and Goergen G, 2014. Phylogeny of Epilachna, Henosepilachna, and some minor genera of phytophagous ladybird beetles (Coleoptera: Coccinellidae: Coccinellinae: Epilachnini), with an analysis of ancestral biogeography and host-plant utilization. Zool. Sci. 31: 820-830.

Khan I, Din S, Khalil SK and Rafi MA, 2007. Survey of predatory coccinellids (Coleoptera: Coccinellidae) in the Chitral district, Pakistan. J. Insect Sci. 7:7.

Lucas E, 2012. Intraguild interactions, in: Hodek, I., van Emden, H.F., Honěk, A. (Eds.),

Ecology and Behaviour of the Ladybird Beetles (Coccinellidae). Blackwell Publishing Ltd., Oxford. pp. 343-374.

Shah ZM, 1985. Ladybird Beetles (Coccinellidae: Coleoptera) of Peshawar region. M. Sc (Hons) Thesis, Department of Entomology, NWFP Agriculture University, Peshawar, Pakistan.

Sutherland AM and Parrella MP, 2009. Mycophagy in Coccinellidae: review and synthesis. Biol. Cont. 51: 284-293.

Moreton BD, 1969. Ladybirds and spider mites. In: Beneficial insects and Mites. Her Majesty, Stationary Office London. Ministry of Agriculture, Fisheries and Food Bulletin. 20:1520.

Mughal TK, Ullah Z, Sabri MA, Ahmad S and Hussain D, 2017. In vitro comparative toxicity of different insecticides against adults of seven spotted beetle, Coccinella septempunctata L. (Coleoptera: Coccinellidae). Coleoptera: Coccinellidae). J. Entomol. Zool. Stud. 5: 498502.

NBAII, 2009. Factsheets on Agriculturally Important Insects.

http://www.nbaii.res.in/Featured\%20insects/featu red-insects.html

Obrycki JJ and Kring TJ, 1998. Predaceous Coccinellidae in biological control. Annual review of entomology. Annu. Rev. Entomol. 43:295-321.

Poorani J, 2002. An annotated checklist of the Coccinellidae (Coleoptera) (excluding Epilachninae) of the Indian subregion. Orient. Insects. 36: 307-383.

Rafi AM, Irshad M and Inaytullah M, 2005. Predatory Ladybird beetles of Pakistan. Blue Area (Islamabad, Pakistan), Rohani Art Press. p. 107.

Rahatullah H, Mehmood F, Saeed SA and Rehman S, 2011. Diversity and distribution of ladybird beetles in District Dir Lower, Pakistan. Int. J. Biodivers. Conserv. 3: 670-675.

Robertson JA, Ślipiński A, Moulton M, Shockley FW, Giorgi A, Lord NP, Mckenna DD, Tomaszewska W, Forrester J, Miller KB and Whiting MF, 2015. Phylogeny and classification of cujoidea and the recognition of a new superfamily Coccinelloidea (Coleoptera: Cucujiformia). Syst. Entomol. 40: 
745-778.

Seago AE, Giorgi JA, Li J and Ślipiński A, 2011. Phylogeny, classification and evolution of ladybird beetles (Coleoptera: Coccinellidae) based on simultaneous analysis of molecular and morphological data. Mol. Phylogenet. Evol. 60: 137.

Slipinski SA, 2007. Australian Ladybird Beetles (Coleoptera: Coccinellidae). Department of the Environment and Water Resources, Canberra. p.286.

Urooj Z and Ali A, 2016. Ladybird beetles (Coleoptera: Coccinellidae) fauna of District Swabi, Nowshera and Mardan. Int. J. Agric.
Environ. Res. 2: 86-92.

\section{Contribution of Authors}

Bodlah MA: Collected the samples and wrote the paper

Bodlah I: Designed research methodology

Rasheed MT \& Fareen AGE: Species mapping and identification

Ikram K: Reviewed \& edited manuscript

Iqbal Z: Species Photography

Zada R: Provided the guidelines 